\title{
The social impact of mine closure in the Jiu Valley
}

\author{
Izabella Kovacs*, Sorin Simion, Alin Irimia, Ligia Ioana Tuhuţ, and Gheorghe Daniel \\ Florea
}

National Institute for Research and Development in Mine Safety and Protection to Explosion INSEMEX Petrosani, 32-34 G-ral Vasile Milea Street, Petrosani 332047, Romania

\begin{abstract}
The impact of transition periods is experienced by the local population and economy as a result of mining activities closure and dismissal of a large number of workers followed by diversification of employment and career reorientation opportunities. The aim of the paper is to highlight the impact generated by closure of mining operations on local society and economy as well as identifying opportunities for harmonious development of communities in the Jiu Valley. Following the assessment of the social impact of mining activities closure, we found a rising tendency of unemployment rate among the middle-aged population that did not benefit from vocational retraining and the growing tendency of young people to leave the region for strictly economic reasons leading to widespread social aging.
\end{abstract}

\section{Restructuring of mi ning activity in Romania and the Jiu Valley}

Jiu Valley is a micro-region in Hunedoara County, located between the Retezat and Parâng Mountains (fig.1). It consists of 3 cities: Petrila, Uricani and Aninoasa and 3 municipalities - Petroșani, Lupeni and Vulcan. Officially, the micro-region has no rural areas, because it has been incorporated into municipalities or cities, being considered urban.

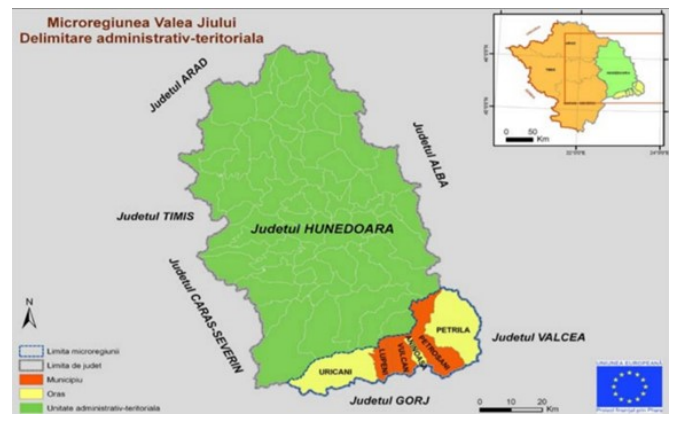

* Corresponding author: izabella.eisler@insemex.ro 
Fig. 1. Location of the Jiu Valley

Immediately after the fall of communism, mining unions in the Jiu Valley became important partners of political forces that supported the slow economy reform. In return of this support, the beginning of the reform was made by increasing wages, reducing the working week to five days, by six hours a day and a fall in coal production by almost $50 \%$ in 1990. This political decision not only delayed the mining sector's restructuring, but increased the economic and social costs of the process that really started with the 1997 wave of redundancies [1]. The year 1997 marks the beginning of government efforts to restructure the mining industry. Closure of mines was not an end in itself, but part of a "move to restructure the economy of the Jiu Valley by replacing its dependence on the mining industry with a diverse range of sectors of activity, business and qualifications" [2].

The dismissal offer consisted of a generous package, of up to 20 compensatory monthly wages. The haste with which people accepted the compensation package far exceeded expectations of the government and the unions. In the Jiu Valley in 1990 there were 54,000 employees of the mining sector, and in 1997, at the time of the layoffs, there were 45,000, of which 20,000 were laid off in the same year [3,4].

The government expected a large proportion of those who accept the compensation package to return to their home regions, but this expectation proved to be inaccurate. The availability of such a large number of workers in industry and the low level of migration has precipitated a sharp decline in general economic activity of mining regions [4]. The net migration rate is calculated as difference between the number of immigrants and the number of emigrants, divided by population and multiplied by 1000 , and if the indicator is negative it means that there are more people leaving the area than those who come to live in the area. Figure 2 highlights the evolution of net migration in the Jiu Valley between 1992 2018 [5]. It is important to note that this statistic only takes into account persons who have moved to / from the Jiu Valley and notified the authorities through the relevant documentation. The statistics do not take into account persons who have left without notification or persons who are still registered in one of the cities in the Jiu Valley, although they live elsewhere.

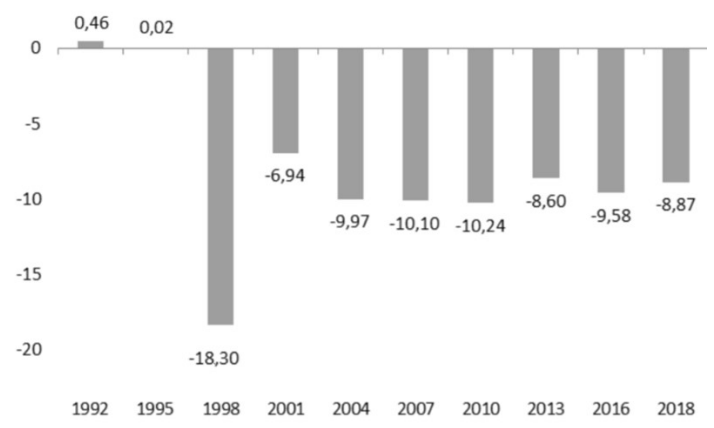

Fig. 2. Evolution of net migration in the Jiu Valley between 1992 - 2018 [5]

As the amounts received as compensatory payments by the first large group of workers were largely consumed in a short time, correlated with the fact that employment options in the mining regions were extremely limited, the acceptance of redundancy offers fell dramatically. Mining unions went on strike in protest of high unemployment and poor results of efforts to create new jobs in mining regions.

In November 2019, Romania adopted the Emergency Ordinance no. 69/2019 [6] for the application of social protection measures granted to persons made redundant through collective redundancies, based on redundancy plans of the National Mine Closure Company Valea Jiului S.A. and the Complexul Energetic Hunedoara S.A. in the period 2019-2024. 
The ordinance provides for granting of monthly supplementary income, as a social protection measure that benefits persons made redundant.

\section{Current social and economic conditions of the Jiu Valley}

Imposition of the EU and IMF conditions for the restructuring of the mining and energy sector in Romania, means that, currently, the underground coal production is carried out by the Mining Division of the Hunedoara Energy Complex $(\mathrm{CEH})$, through four mining operations located in the Jiu Valley (EM Lonea, EM Livezeni, EM Vulcan, EM Lupeni). The total number of employees is approx. 4000, of which 2269 in mining activity. 10 mining objectives were closed in the Jiu Valley [7].

The European Commission has recommended Romania to increase the level of ambition for 2030 to a share of renewable energy of at least $34 \%$. As a result, the level of ambition regarding the share of energy from renewable sources has been revised from an initially proposed share of $27.9 \%$ to a share of $30.7 \%$ [8]. The new target was calculated mainly on the basis of the Commission's recommendation to align national macroeconomic forecasts with those of the "Aging Report Economic and Budgetary Projections for the $28 \mathrm{EU}$ Member States (2016-2070)", correlated with the decommissioning of coal capacity.

Starting with 2018, the Mining Division of CEH remained the only coal producer in Romania. The coal production of the Jiu Valley is used for the production of electricity and heat in the two thermal power plants, Paroșeni and Mintia, located in Hunedoara County.

Although exploitable resources allow the follow on of extractive industry, there are other factors that require the restriction of exploitation and reconsideration of the energy strategy at national level: human resources are aging; exploitation technologies are physically and morally worn out; investment in new mining technologies is low, as no state aid is granted except for the closure and greening of mining perimeters; the constraints imposed by environmental legislation, the reduction of emissions of polluting gases and greenhouse gases; dependence of coal production on the operation of a small number of energy production capacities; orientation towards other renewable energy resources [9].

Currently, the region offers relatively few viable employment alternatives, so jobseekers have to relocate to other cities or even abroad. In 2019, the Jiu Valley recorded approx. 100,000 employable people, aged between 15 and 65. Only a quarter of them are employed, compared to 1992 when over $60 \%$ of the population had a stable job (Fig. 3).

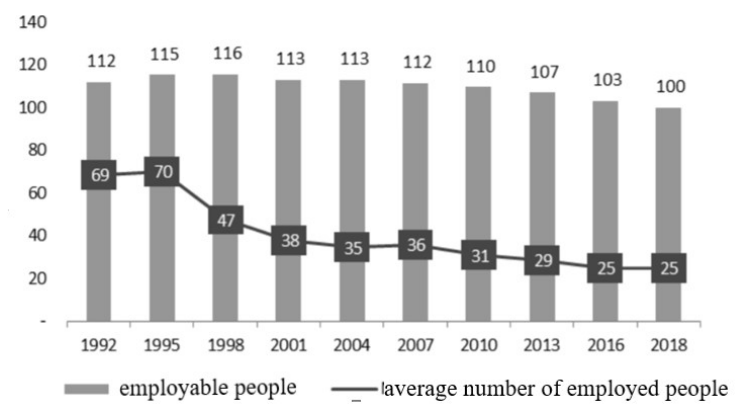

Fig. 3. Evolution of the labour force in the Jiu Valley during 1992-2018 [5]

Statistics show that the number of unemployed decreased between 2010 and 2019 at a rapid pace, but we can see a difference between the number of unemployed and the number of those who can work but do not have a job. This situation occurs because, from a statistical point of view, the unemployed person is a person registered with the National 
Agency for Employment and who meets certain criteria, according to law. The evolution of the unemployed in the Jiu Valley between 2010-2019 is highlighted in fig. 4.

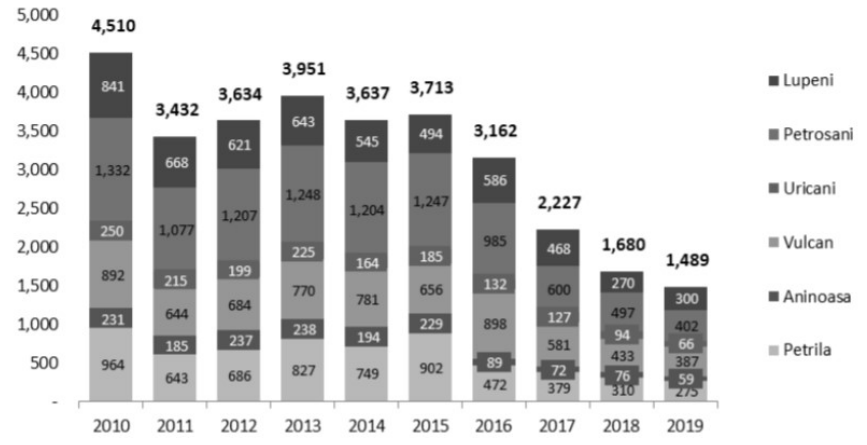

Fig. 4. Evolution of the unemployed in the Jiu Valley between 2010-2019 [5]

The high rate of jobseekers could lead to financial difficulties and poverty, further triggering a number of social problems. As the number of employable people in the Jiu Valley is relatively high, vocational retraining and job creating programs in the region could have a high chance of success.

If we refer to the way the population of Jiu Valley felt the mining restructuring, with the closure of the mines and the related layoffs, a study conducted in 2016 revealed the following situation:

Table 1 To what extent has the restructuring of the mining industry in the area affected the following issues? [3]

\begin{tabular}{|l|c|c|}
\hline & $\begin{array}{l}\text { To a very small extend + a } \\
\text { small extend (\%) }\end{array}$ & $\begin{array}{l}\text { To a large extend + to a } \\
\text { very large extend (\%) }\end{array}$ \\
\hline Access to work & 12 & 82 \\
\hline Quality of life in the area & 33 & 62 \\
\hline Citizen's safety & 44 & 48 \\
\hline Quality of medical acts & 45 & 39 \\
\hline Family income & 59 & 38 \\
\hline Infrastructure quality & 54 & 37 \\
\hline Quality of education & 47 & 34 \\
\hline Personal family life & 70 & 25 \\
\hline Professional development & 71 & 23 \\
\hline
\end{tabular}

The biggest problem the Jiu Valley is facing, from the perspective of its inhabitants, is the lack of jobs. Also, the main problem faced by inhabitants themselves is also of an economic nature, namely poverty / low income.

Table 2 What is the most important issue you think your locality is facing? [3]

\begin{tabular}{|l|l|}
\cline { 2 - 2 } \multicolumn{1}{c|}{} & $\%$ \\
\hline Lack of jobs & 70 \\
\hline Poor condition of roads & 4 \\
\hline Low standard of living & 3 \\
\hline Pollution, waste/garbage & 3 \\
\hline Infrastructure & 2 \\
\hline Lack of economic development & 1 \\
\hline
\end{tabular}




\begin{tabular}{|l|l|}
\hline Poor utilities condition & 1 \\
\hline Lack of authorities' involvement & 1 \\
\hline Repairs to buildings & 1 \\
\hline Lack of investments & 0.5 \\
\hline Poor condition of green spaces, parks & 0.5 \\
\hline Others & 4 \\
\hline No issue & 1 \\
\hline I don't know, I won't answer & 7 \\
\hline
\end{tabular}

Table 3 What is the most important issue you are currently facing personally? [3]

\begin{tabular}{|l|l|}
\cline { 2 - 2 } \multicolumn{1}{l|}{} & $\%$ \\
\hline Low income/poverty & 18 \\
\hline Lack of jobs & 13 \\
\hline Bad health & 10 \\
\hline Infrastructure & 2 \\
\hline Poor conditions of roads & 1 \\
\hline Poor condition/lack of utilities & 1 \\
\hline Migration & 1 \\
\hline Poor administration & 1 \\
\hline Education & 1 \\
\hline Poor state of buildings & 1 \\
\hline High prices/taxes & 1 \\
\hline Pollution/waste & 1 \\
\hline Others & 5 \\
\hline No issue & 30 \\
\hline I don't know, I won't answer & 15 \\
\hline
\end{tabular}

Demographic analysis of the Jiu Valley indicates a decrease in population since 1998, being generally accepted that this population decline was triggered by layoffs and restructuring of the mining industry (Fig. 5).

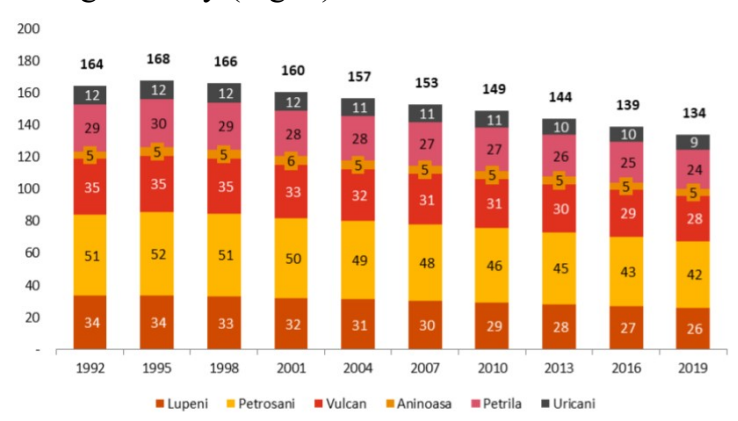

Fig. 5. Population evolution in each municipality of Jiu Valley between 1992-2019 [5]

Those who leave the Jiu Valley have as their main reason the limited number of employment opportunities, especially for young people with higher education. The trend is also seen among young people who want to pursue a career in various industries that are not present in the Jiu Valley. The number of people returning to the Jiu Valley after completing their studies is very low due to various factors, mainly the limited number of jobs available and the high demand in other regions of Romania. In addition to population declining, we are also witnessing its aging, with an impact on the workforce, educational requirements, health and social services. Data from the National Institute of Statistics 
indicate that the percentage of people over 45 increased by 45\% in 2019 compared to 1992 (Fig. 6) [4].

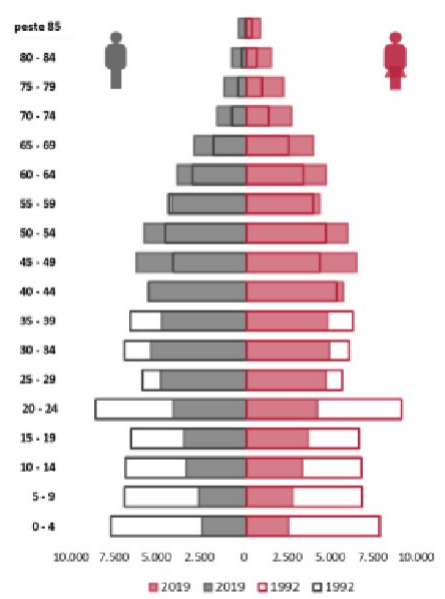

Fig. 6. Jiu Valley population by age and gender (1992 vs 2019) [5]

\section{Conclusions}

The main challenges Jiu Valley is facing lie in the fact that this area is mono-industrial and the industry that is the main source of income for a large part of the population is being restructured. The European Union's policy is to close mines and economically convert mono-industrial basins. Coal-based energy production is no longer cost-effective, and climate change is becoming increasingly stringent. By 2030, most EU mining basins should have a future plan that does not include coal as the only form of survival [6].

Poverty is a reality found empirically but mainly in the suburbs of the Jiu Valley [10]. Residents point to the lack of jobs as the main difficulty in the area where they live, but at the same time $30 \%$ of residents say they personally do not face any problems and half of those who have experienced mine closure say their lives are about the same. after closure as before this phenomenon [3].

The number of inhabitants is decreasing, we can see a process, significant in recent years, of population aging and limited employment opportunities determine young and qualified to leave the area, migrating to other places that offer viable employment opportunities.

Although resistance to change and requalification of current or former miners is relatively high, the technical and professional skills of mining technicians are easily transferable to the renewable energy and energy distribution sectors, and professional retraining can allow them to work in installation, operation and maintenance of renewable energy projects and electricity networks. Development of the energy network can attract the interest of renewable energy companies. If the electricity transmission network were modernized and the connection to the grid were cheaper, the economic development opportunities of the Jiu Valley would diversify, as renewable energy companies could show interest in the development of wind or solar power plants.

\section{References}


1. J. Bruha, D. Ionascu, B. Jeong, Organized Labour and Restructuring: Coal Mines in the Czech Republic and Romania (pp. 49-72), Physica-Verlag HD, (2010)

2. H.G. nr. 646/2002 on the approval of the Socio-economic Development Strategy of the Jiu Valley Coal Basin, (2002)

3. Romanian Institute for Evaluation and Strategy - IRES "Miners - between public perceptions and self-perception", on line at https://ires.ro/articol/332/minerii--intreperceptii-publice-si-auto-percep $\% \mathrm{C} 5 \%$ A3ie, (2016)

4. M. Haney, M. Shkaratan, Mine closure and its impact on the community: five years after mine closure in Romania, Russia and Ukraine, Social Development Papers, Paper no.42, (2003)

5. PwC Romania, Strategy for the coal transition in the Jiu Valley Analysis of the main challenges and opportunities in the Jiu Valley, On line at http://mfe.gov.ro/wpcontent/uploads/2020/07/b02b3d268774f9adb3c9f655c452aa87.pdf, (2020)

6. Emergency Ordinance no. 69/2019 for the application of social protection measures granted to persons made redundant through collective redundancies carried out on the basis of redundancy plans within economic operators for which it was approved to grant state aid to facilitate the closure of uncompetitive coal mines in 2019-2024, Official Monitor, Part I no. 921 of November 14, (2019)

7. Ministry of Economy, Energy and Business Environment, Romania's energy strategy 2019-2030, with the perspective of 2050, on line at

http://energie.gov.ro/transparenta-decizionala/strategia-energetica-a-romaniei-2019-2030cu-perspectiva-anului-2050/

8. Ministry of Economy, Energy and Business Environment, Integrated National Plan in the field of Energy and Climate Change 2021-2030, (2020), online at

https://ec.europa.eu/energy/sites/ener/files/documents/ro_final_necp_main_ro.pdf

9. C. Tomescu, E. Chiuzan, D. Cioclea, N. Ianc, C. Boanta, Reducing the coal operating capacities in romania in the context of national energy self-sufficiency and safety insurance, $S G E M$, (in process of publication), (2020)

10. https://www.valeajiuluiimplicata.org/project/adresa-cu-privire-la-documentul-strategiepentru-tranzitia-de-la-carbune-in-valea-jiului-analiza-principalelor-provocari-sioportunitati-din-valea-jiului/ 